\title{
COMMODITY STUDY OF DEVELOPED CUPCAKES OF ORGANIC RAW MATERIALS
}

\author{
Alina Tkachenko \\ ialina_biaf@ukr.net \\ Ivan Syrokhman \\ Department of Commodity Science, Technologies and Food Quality Management ${ }^{3}$ \\ syrokhman@ukr.net \\ Yulia Basova ${ }^{1}$ \\ basovay5@gmail.com \\ Anna Kobischan ${ }^{1}$ \\ kobischan@gmail.com \\ Anna Artemenko \\ International Economics Department ${ }^{2}$ \\ annaartemenko5@gmail.com \\ Khrystyna Kovalchuk ${ }^{4}$ \\ khristinakovalchuk@i.ua \\ Olena Kalashnyk \\ Department of entrepreneurship and law \\ Poltava State Agrarian Academy \\ 1/3 Skovorody str., Poltava, Ukraine, 36003 \\ kalashnik1968@meta.ua \\ Mariia Katruk \\ PhD, Senior Lecturer \\ Department of entrepreneurship and marketing \\ Ukrainian academy of printing \\ 19 Did Holoskom str., Lviv, Ukraine, 79000 \\ katrukmariya@i.ua \\ Roman Zakharchyn \\ PhD, Associate Professor ${ }^{4}$ \\ zakharchyn@555gmail.com \\ Volodymyr Havrylyshyn \\ PhD, Associate Professor \\ Department of commodity science, technology and quality management of food products ${ }^{3}$ \\ volodymyrlka@ukr.net \\ ${ }^{1}$ Department of Commodity research, biotechnology, examination and customs \\ ${ }^{2}$ Poltava University of Economics and Trade \\ 3 Kovalya str., Poltava, Ukraine, 36014 \\ ${ }^{3}$ Lviv Trade and Economic University \\ 10 Tugan-Baranovskoho str., Lviv, Ukraine, 79000 \\ ${ }^{4}$ Department of Commodity Research and Commodity Expertise \\ Lviv Institute of Economics and Touris \\ 8 Mentsynskyi str., Lviv, Ukraine, 79007
}

Abstract

For widening the assortment of floury confectionary products of organic raw materials, recipes of new cupcakes of sandy dough "Cosmic" and "Lunik" were offered. 
The recipe of cakes "Cosmic" included the organic raw materials: rice flour, grinded ginger, lemongrass powder, coconut sugar, creamy butter and sea buckthorn oil, mélange of chicken eggs, black ashberry jam. The recipe of cakes "Lunik" included rice flour, combined with spelt one, lemongrass powder, coconut sugar, creamy butter and sea buckthorn oil, mélange of chicken eggs, organic blackberry jam. A control sample was baskets with jelly and fruits, prepared by the traditional recipe. The main difference of the offered samples is in fact that they are prepared of the organic raw materials only. Margarine is a fatty base of the control sample. It is offered to replace the fatty base by creamy butter and sea buckthorn oil. The production technology of a sandy semi-product consists of four stages: preparation of raw materials for production, preparation of a sandy semi-product, its formation, baking. This paper offers the developed scale of organoleptic estimation of the cupcake quality and presents results of studying its food value. The highest quality level by organoleptic parameters was fixed in the "Lunik" sample - 0.96; in the "Cosmic" sample, the quality level is also rather high -0.95 ; the control sample differed by much lower quality level -0.83 . The developed samples differed by lower energetic value, namely, $351.00 \mathrm{kcal}$ and $313.50 \mathrm{kcal}$ in the "Cosmik" and "Lunik" samples, respectively, whereas for the control sample this number was $433.70 \mathrm{kcal}$. The offered recipes of cupcakes included the higher protein content than the control - 7.40 and $7.58 \mathrm{~g} / 100 \mathrm{~g}$ for "Cosmic" and "Lunik" samples, respectively, whereas the protein content in the control was $5.40 \mathrm{~g} / 100 \mathrm{~g}$.

Keywords: safety management system, fatty-acid composition, floury confectionary products, content of toxic elements.

DOI: $10.21303 / 2504-5695.2020 .001201$

\section{Introduction}

An essential number of scientific works is devoted to the improvement of consumption properties of cupcakes. Thus, it has been established, that introduction of pea flour and sunflower kernels to the recipe of developed sandy cupcakes gives a possibility to increase the content of irreplaceable amino acids in the protein composition of the developed product in average by $62-77 \%$ [1]. But this study didn't relate to organic food products. Researches [2, 3] are devoted to studying consumption properties of floury confectionary products of organic raw materials. These studies indicate that products of organic raw materials differed by higher consumption properties and better safety parameters. But these studies dealt with fruitcakes and biscuits that is why scientific searches just in development of new cupcakes of organic raw materials are topical.

At developing new food products, it becomes important to estimate their organoleptic quality parameters. Just that is why the great scientific interest belongs to searches for improving existent scales of point estimation. There are data about the improvement of the organoleptic estimation scale for fruitcakes. Quality parameters, influenced the acceptability of samples were color, smell, texture and taste. The advantage order of the quality parameters was the following: taste $>$ smell $>$ texture $>$ color [4]. There were also used methods for the organoleptic estimation of floury confectionary products, based on illegible logic [5].

At developing new products, the study of food value - proteins, lipids and carbohydrates also gains the special importance [6]. Based on it, the aim of the paper is the commodity study of the developed cupcakes of organic raw materials.

The aforesaid data stress the expedience of widening the assortment and developing new products of organic raw materials. As far as the essential segment of the product market is occupied by floury confectionary products, the study of developed products of just this group is offered. It must be noted, that consumers pay attention now not only to the quality and safety of food products, but also to their biological value. That is why the recipes of new floury products with improved consumption properties, produced of organic raw materials, are offered in the work.

\section{Materials and Methods}

At developing new products, the special attention is now concentrated on organoleptic parameters and requirements of the national standard SSU 4803:2007 «Cakes and cupcakes. General technical conditions». According to this standard, the good outlook, even and well-baked surface, diverse forms without breaks must be inherent to the product.

The organoleptic quality estimation of the new products was carried out according to the requirements of the existent standard SSU 2781-98 and based on the 50-point quality estimation 
scale, developed by us (Table 1). It was carried out by the sensor method by parameters, provided by the standard: form, surface, color, look of a slice, smell, taste. We also added the new parameters: "aftertaste" and "outlook". The maximal mark of 5 points is provided for each quality parameter, and ponderability coefficients were determined for them. The quality level by the organoleptic parameters was determined by the formula:

$$
X=a 1 B 1+a 2 B 2+\ldots+a n B n,
$$

where $a$-ponderability coefficient of a single parameter; $B$ - mark in points of a separate parameter [6].

According to the data of previous studies of organoleptic properties of cupcakes, highlighted in source [7], the most essential parameters are consistence, outlook, taste and smell.

Table 1

Developed quality estimation scale for cupcakes

\begin{tabular}{|c|c|c|c|}
\hline No. & Quality parameter & Ponderability coefficient & Maximal point \\
\hline 1 & Form & 1 & 5 \\
\hline 2 & Surface & 1 & 5 \\
\hline 3 & Color & 1 & 5 \\
\hline 4 & Outlook & 1 & 5 \\
\hline 5 & Look in slice & 1 & 5 \\
\hline 6 & Consistence & 0.5 & 5 \\
\hline 7 & Smell & 1.5 & 5 \\
\hline 8 & Taste & 2 & 5 \\
\hline 9 & Supplement intensity & 0.5 & 5 \\
\hline 10 & Aftertaste & 0.5 & 5 \\
\hline \multicolumn{3}{|c|}{ Total number of points } & 50 \\
\hline
\end{tabular}

An important factor in organic products is a microelement composition, considered mainly from the point view of biological necessity. The human activity resulted in the contamination increase in the environment, the redistribution of microelements and contamination of agricultural products with toxic elements took place [8].

For studying the content of toxic elements in new cupcakes, the following methods were used: copper, zinc, lead and cadmium were determined by the atom-absorption method, mercury by the method of flameless atomic absorption, arsenic - by the colorimetric method. The atom-absorption method is one for determining a concentration, relative to absorbing monochromic light element by the steam layer. A sample of a substance that the necessary element must be determined in is pulverized as a stream of small drops. A little amount of this stream is transferred to a closet of atomization with flame as an atomizer. A solvent (most often water) instantly evaporates in the high-temperature medium of the atomization closet, leaving particles of the analyzed substance. These particles fast transform in gas-like molecules, free neutral atoms or ions, able to absorb. The analysis is realized according to the grading graph, constructed in the system of coordinates: atomic absorption (analytic signal) - concentration of the element in the analyzed solution [9]. The method of colorimetric analysis is based on reactions of creation or destruction of colored compounds, ones, able to absorb light. At creating a colored compound, the amount of the reaction product is proportional to the coloration intensity. The destruction of the colored compound is correspondingly characterized by the coloration intensity decrease, proportional to the reaction product amount [10].

The food and energetic value of cupcakes was determined by the calculating method [11, 12]. 


\section{Results}

Organoleptic parameters were first turn estimated in the new products, because they have the most essential importance for consumers. The estimation results are presented in Table 2.

Table 2

Total gustatory quality estimation of the new cupcakes

\begin{tabular}{|c|c|c|c|c|c|}
\hline No. & Parameter & Ponderability coefficient & Control & «Cosmic» & «Lunik» \\
\hline 1 & Form & 1 & 4.5 & 4.67 & 4.89 \\
\hline 2 & Surface & 1 & 4.34 & 4.67 & 4.67 \\
\hline 3 & Color & 1 & 4.34 & 5 & 4.89 \\
\hline 4 & Outlook & 1 & 4.44 & 4.78 & 4.9 \\
\hline 5 & Look in slice & 1 & 4.22 & 4.68 & 4.9 \\
\hline 6 & Consistence & 0.5 & 2.03 & 2.03 & 2.03 \\
\hline 7 & Smell & 1.5 & 6.84 & 7.2 & 7.2 \\
\hline 8 & Taste & 2 & 9 & 9.8 & 9.8 \\
\hline 9 & Supplement intensity & 0.5 & 0 & 2.4 & 2.5 \\
\hline 10 & Aftertaste & 0.5 & 2 & 2.39 & 2.38 \\
\hline \multicolumn{3}{|c|}{ Total number of points with the ponderability coefficient } & 41.71 & 47.62 & 48.16 \\
\hline
\end{tabular}

So, according to the data of Table 2, the developed products differ by the high organoleptic indices. Especially, samples obtained more points comparing with the control sample by the parameter "taste" -9.8 respectively, whereas the control one obtained only 9 points. The new samples obtained 7.2 points by the parameter "smell", whereas the control sample - only 6.84 . The total amount of points was: for the control sample -41.71 points; for the sample "Cosmic" -47.62 ; for the sample "Lunik" - 48.16, The quality level of the samples by the organoleptic parameters is presented on Fig. 1.

So, based on the data of Fig. 1, the highest quality level by the organoleptic parameters was fixed in the sample "Lunik" - 0.96; The quality level of the sample "Cosmic" was also rather high -0.95 ; the control sample differed by much lower quality level.

Parameters of the food and energetic value are also studied in the research and presented in Table 3.

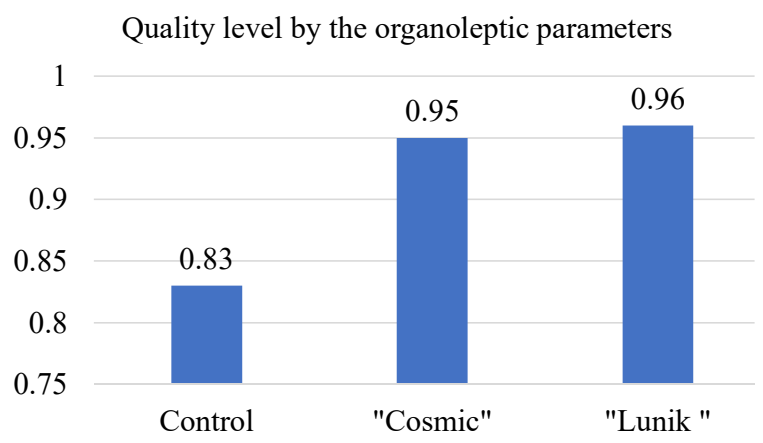

Fig. 1. Quality level of the developed cupcakes by the organoleptic parameters

So, according to the food and energetic value indices, presented in Table 3, the developed samples exceed the control, because they contain more proteins and less lipids and carbohydrates and also differ by lower energetic value. 
The safety indices (content of toxic elements) in the developed products didn't exceed maximal permitted levels, set by the requirements of normative documents, and that testifies to safety of the used raw materials and possibility to produce them.

Table 3

Food and energetic value of the developed cupcakes

\begin{tabular}{ccccc}
\hline Product name & Proteins, $\mathbf{g} / \mathbf{1 0 0} \mathbf{g}$ & Lipids, $\mathbf{g} / \mathbf{1 0 0} \mathbf{g}$ & Carbohydrates g/100 g & Energetic value, $\mathbf{k c a l} / \mathbf{1 0 0} \mathbf{g}$ \\
\hline Control & 5.40 & 28.5 & 38.9 & 433.7 \\
«Cosmic» & 7.40 & 22.2 & 30.40 & 351.00 \\
«Lunik» & 7.58 & 18.4 & 29.40 & 313.50
\end{tabular}

\section{Conclusions}

For widening the assortment of organic floury confectionary products, 2 recipes of cupcakes with fruit fillers "Cosmic" and "Lunik", containing the fully organic raw materials, were developed. The organoleptic parameters of the developed products essentially exceeded the control. A part of fat was replaced for sea buckthorn oil for improving the fatty acid composition.

The samples exceed the control by the organoleptic parameters. The highest quality level by the organoleptic parameters was fixed in the sample "Linik"- 0.96; the quality level of the sample "Cosmic" was also rather high - 0.95; the control sample differed by much lower quality level. According to the food and energetic value indices, the developed samples exceed the control, because they contain more proteins and less lipids and carbohydrates and also differ by lower energetic value.

The main advantage of the study is the fact that the developed products are made of the fully organic raw materials. Taking into account the fact, that the market of organic products becomes more and more popular among consumers, the results of the scientific study may be used by enterprises of the confectionary branch for widening the assortment of organic food products.

The development of cupcakes of the organic raw materials is a continuation of earlier studies in developing recipes of products of organic raw materials. It is planned to devote further studies to storage terms of the developed products and to searches of packing materials for their storage.

Connected with the fact that the share of organic product consumers constantly increases, especially in European countries, further studies will be also devoted to the search for new recipes of organic raw materials, especially floury and confectionary ones.

\section{References}

[1] Palko, N. S. (2013). Novi tistechka polipshenoho aminokyslotnoho skladu. Kharchova nauka i tekhnolohiia, 18, 54-56.

[2] Tkachenko, A., Syrokhman, I., Lozova, T., Ofilenko, N., Goryachova, E., Hmelnitska, Y., Shurduk, I. (2019). Development of formulations for sponge cakes made from organic raw materials using the principles of a food products safety management system. Eastern-European Journal of Enterprise Technologies, 1 (11 (97)), 60-70. doi: http://doi.org/10.15587/17294061.2019.155775

[3] Tkachenko, A., Birta, G., Burgu, Y., Floka, L., Kalashnik, O. (2018). Substantiation of the development of formulations for organic cupcakes with an elevated protein content. Eastern-European Journal of Enterprise Technologies, 3 (11 (93)), 51-58. doi: http://doi.org/10.15587/1729-4061.2018.133705

[4] Vinti, S., Sandeep, K., Jyotsana, S., Rai, A. K. (2018). Fuzzy Logic Sensory Evaluation of cupcakes developed from the mahua flower (Madhuca longifolia)», International Journal of Emerging Technologies and Innovative Research, 5 (1), 411-421.

[5] Singh, K. P., Mishra, A., Mishra, H. N. (2012). Fuzzy analysis of sensory attributes of bread prepared from millet-based composite flours. LWT - Food Science and Technology, 48 (2), 276-282. doi: http://doi.org/10.1016/j.lwt.2012. 03.026 
[6] Nazar, M. I., Kocherha, V. I. (2012). Vyznachennia vitaminno-mineralnoho skladu vyrobiv z biskvitnoho tista na osnovi boroshnianykh sumishei i fitokompozytsii. Kharchova nauka i tekhnolohiia, 3 (20), 59-62.

[7] Matyiashchuk, O. V., Bashkirova, N. V. (2017). Udoskonalennia retseptury shokolodanykh tistechok «Brauni», zbahachenykh llianym ta vivsianykh boroshnom Molodyi vchenyi, 2 (42), 192-196.

[8] Polishchuk, A. A., Bulavkina, T. V. (2009). Doslidzhennia toksychnosti vazhkykh metaliv u svynarstvi. Visnyk Poltavskoi derzhavnoi ahrarnoi akademii, 1, 53-56.

[9] Viatkin O., Haponova R. (2010). Analizuvannia metodiv vyznachennia pokaznykiv bezpeky kharchovykh produktiv. Standartyzatsiia, sertyfikatsiia, yakist, 3, 43-45.

[10] Paska, M., Simonova, I., Galuch, B., Basarab, I., Masliichuk, O. (2017). Toxic elements in lentil, thyme and juniper in the composition of semi-smoked sausages using the method of atomic-absorption spectrometry with atomization in flame. EUREKA: Life Sciences, 4, 35-42. doi: http://doi.org/10.21303/2504-5695.2017.00388

[11] Zucco, F., Borsuk, Y., Arntfield, S. D. (2011). Physical and nutritional evaluation of wheat cookies supplemented with pulse flours of different particle sizes. LWT - Food Science and Technology, 44 (10), 2070-2076. doi: http://doi.org/10.1016/j.lwt. 2011.06.007

[12] Lozova, T. M., Kovalchuk, K. (2013). Tovaroznavchi doslidzhennia zberihannia novykh keksiv. Visnyk Lvivskoi komertsiinoi akademii. Seriia tovaroznavcha, 13, 11-13. 